\title{
Erratum to: Review of Molecular Simulation Method for Gas Adsorption/desorption and Diffusion in Shale Matrix
}

\author{
WANG Hui ${ }^{1,2}$, QU Zhiguo ${ }^{2 *}$, YIN Ying ${ }^{2}$, BAI Junqiang ${ }^{1}$, YU Bo ${ }^{3}$ \\ 1. School of Aeronautics, Northwestern Polytechnical University, Xi'an, Shaanxi 710072, China \\ 2. MOE Key Laboratory of Thermo-Fluid Science and Engineering, School of Energy and Power Engineering, Xi'an \\ Jiaotong University, Xi'an, Shaanxi 710049, China \\ 3. Mechanical Engineering College, Beijing Institute of Petrochemical Technology, Bejing 102617, China \\ (c) Science Press, Institute of Engineering Thermophysics, CAS and Springer-Verlag GmbH Germany, part of Springer \\ Nature 2018
}

\section{Erratum to: Journal of Thermal Science https://doi.org/10.1007/s11630-018-1053-9}

In the originally published article version the family name of first author WANG Hui was misspellt "WAND". The original article has been corrected.

The online version of the original article can be found at https://doi.org/10.1007/s11630-018-1053-9 